various furnaces and factories, it is evident that observations for meteoric and volcanic dust should be made at elevated stations far removed from large cities. If a station were established upon Mount Shasta, California, as suggested by Mr. Gilbert Thompson, it would afford excellent opportunity for such observations. The station on Mount Washington is also favourably situated, and if regular observations were made at these stations and in Alaska for small as well as large quantities of such dust, and the sediments collected subjected to microscopical examination, the result would doubtless be of great interest.

Washington, D.C., March 25

\section{THE POLAR CONFERENCE ${ }^{1}$}

THE Fellows need hardly be reminded that it was at the suggestion of an Austrian, the late Carl Weyprecht, that this great international undertaking was set on foot, and accordingly Vienna was the most fitting city in which to welcome the several expeditions on their return to civilisation, and to discuss the best mode of utilising their labours.

The chiefs of nine expeditions were present at the meeting. The uncepresented stations were the two Russian ones, at Nova Zemlya and at the mouth of the Lena (at which latter station the observations will be continued until August I884); that established by the Society of Science of Finland at Sodankylä, the German station in South Georgia, and the second Amcrican station at Lady Franklin Bay. As to the fate of the observers at the last-named locality there are unfortunately grave reasons for anxiety.

Most of the expeditions had brought home a collection of photographs, giving a vivid representation of their respective surroundings during their sojourn. Many of these possess ethnological interest, and one was humorous, as it showed the Dutch Arctic tin band, with instruments made out of preserved meat canisters.

I suppose my audience is aware that the Dutch Expedition was ice-bound and drifted about in the Kara Sea, ultimately saving itself in its boats. The ship was crushed in the autumn of 1882 , but did not actually sink for six months, so that all the property was saved. Under such circumstances, however, it is no wonder that no magnetical observations were made.

As regards the publications, these are to be carried out independently in each country, but on a uniform plan. The meteorological observations are to be given in metric and centigrade measures ; the magnetical according to the C.G.S. system of units.

The hourly observations are to be published in detail. The barometer observations are not to be corrected for gravity, but the value of this correction is to be given in the tables.

As regards terrestrial magnetism, besides the publication of the term day observations a detailed reproduction of all the observations for certain days of disturbance is to be given. A list of these days will be prepared by Prof. Wild.

All the members of the Conference are requested to collect data for earth currents for their respective countries during the period of the circumpolar observations. The auroral observations are to be published on the scheme proposed by Weyprecht.

As to the magnetic disturbances and their elimination there was, as might be expected, a long debate, but no definite resolutions were adopted.

The publication of a number of observations was left optional, such as evaporation, solar radiation, the resolution of the wind to four components, the calculation of wind-roses according as the pressure was above or below $760 \mathrm{~mm}$., \&c.

It is hoped that the whole of the results will have appeared by the end of 1885 .

The Conference was most graciously received by the Emperor at an audience. The members were also entertained at a magnificent banquet on April 23 by Count Wilczek, at whose sole expense the Austrian Expedition to Jan Mayen had been fitted out and maintained during its stay.

The detailed report of the proceedings of the Conference will be published in French and German, and will appear before long.

\section{GEOLOGY IN RUSSTA}

A LTHOUGH a large amount of geological work has been done in Russia, especially during the last twenty years, the geological exploration of this wide region has not been carried I Notes on the Proceedings of the International Polar Conference, held at Vienna, April 17-24, r884. Read at the Royal Meteorological Society by
Robert H. Scott, F.R.S., President. on in the detailed and accurate manner required by modern geology. An important step towards the attainment of more precise knowledge on this subject was taken in $\mathbf{1} 882$ by the formation of a special Geological Commission intrusted with the geological survey of Russia. A yearly subsidy of 30,000 roubles was granted for that purpose by the State, to which must be added various occasional subsidies for special aims, supplied either by Government or by provincial assemblies and private bodies. This Commission has now published two volumes of its Bulletin and one fasciculus of Memoirs. ${ }^{2}$ From these we learn that the chief work undertaken has been the preparation of a geological map of Russia on the scale of 10 versts $(6.7$ miles) to an inch. Russia has been divided into ten regions : Baltic, Central, Dnieper, Western Frontier, Volga and Don, Caspian, Ural, Crimea and Caucasus, Northern, and Finland. The survey has been started in several regions at once, each region being subdivided into three parts : (I) those which are well explored, and the maps of which already exist and could be employed for geological purposes ; (2) those in which various isolated explorations have been made ; and (3) unexplored parts. The explorations will be prosecuted first of all in the second of these three areas. The system of culours for the map will be adopted which was recommended by the Congress of Bologna. The explanations, as also the chief names, will be printed in French, side by side with the Russian text.

The first volume of the Memoirs contains a work by M. Lahusen, on the Jurassic fauna of the Government of Ryazan, written in Russian, with a summary in German. It is a complete enumeration of the Jurassic fossils of the region, the deposits of which belong-the black clay, with Cardioceras cordatum, to the Lower Oxfordian; the oolitic gray clay, with iron and Cardioceras lamberti, to the Upper Callovian ; the gray and brown clays, with Perisphinctes mosquensis and mutatus, to the Middle; and the brown iron sandstone, with sheets of black clay and characterised by Cosmoceras gowerianum, Cardioceras chamusseti, and Stephanoceras elatine, to the Lower Callovian. The new fossils of the Aucella sandstone will be described by M. Nikitin. Eleven quarto plates illustrating a great number of species, many of which are new, accompany the paper.

The Bulletin (Iavestia) contains, besides the minutes of meetings, a number of preliminary reports of the geologists of the Survey, and the description, by M. Nikitin, of the sheet 58 (Yaroslavl) of the geological map of Russia. These notices are full of valuable information regarding the details of the geological structure of Russia. Among papers of more general interest we may mention Prof. Fr. Schmidt's report upon his explorations on the Baltic Railway, which embodies the results of his prolonged researches in the same region (vol, ii. fasc. 5). It has long been known that Esthonia is built up of Silurian formations, from beneath which rises the Cambrian Ungulite sandstone characterised by Obolus apollinis. After the emergence of the Silurian deposits, the country remained for a vast period a barren land undergoing atmospheric denudation. During this long lapse of time the terrace of the Glint, which runs from Lake Ladoga to Baltisch Port, was formed. During the Glacial period the country was covered with an immense ice-sheet, which moved south-west in its western parts, due south in the middle, and south-east in its eastern parts. The bottom moraine of this ice-sheet spreads over the country, and consists of a mixture of far-transported bulders with debris of the local rocks. It is the equivalent of the British Till and of the Swedish Krossstensgrus. It sometimes gets the local name of Richk. It rises into elongated hills or "drums," which extend also throughout the Government of Novgorod, and must be distinguished from the Åscar. These last, in the opinion of Prof. Schmidt, who indorses the explanation of A. Törnebohm, are shore-walls of those mighty sub-glacial rivers, so well described by Nordenskjöld, which circulate on the surface of the icesheets, and, after having found an exit through the ice, run beneath it.

During the first part of the Post-Glacial period the Gulf of Finland, and probably all the northern part of the Baltic Sea, formed an immense lake which subsequently was connected with the ocean, and received its brackish-water fauna. The level of this lake was about 60 feet higher than the present level of the Baltic. The presence of Baltic shells at grenter heights in the north (the author of this notice found them at 124 feet, on

I Irvestia geologicheskago Komiteta, vols. i, and ii, (fasc. I to 6), 1882 and $1883 .-$ Trudy geologicheskago Komiteta, vol. i. lasc. I; 4 to. (St Petersburg, I883.) 